\title{
Article
}

\section{Removal of Perchlorate Ion in Tap Water with Montmorillonite Modified with Hexadecylpyridinium Chloride}

\author{
Yoji MAKITA $^{{ }^{*}}$, Ramesh CHITRAKAR ${ }^{1}$ and Akinari SONODA ${ }^{1}$ \\ ${ }^{I}$ Health Research Institute, National Institute of Advanced Industrial Science and Technology (AIST), \\ 2217-14 Hayashi, Takamatsu 761-0395, Japan
}

(Manuscript received May 28, 2014; Accepted July 24, 2014)

\begin{abstract}
Removal of perchlorate ion in tap water with montmorillonite which modified with hexadecylpyridinium chloride (CPC-montmorillonite) was investigated by column chromatography. Almost all anions except $\mathrm{Cl}^{-}$ion in a tap water containing 0.518 and $0.540 \mathrm{mg} \mathrm{dm}^{-3}$ on average of perchlorate ion $\left(\mathrm{ClO}_{4}^{-}\right)$and bromate ion $\left(\mathrm{BrO}_{3}{ }^{-}\right)$, respectively, through the CPC-montmorillonite bed, are adsorbed at the beginning of the column experiment, whereas the $\mathrm{Cl}^{-}$concentration in effluent immediately increases steeply. The anions exhibit breakthrough in the order of $\mathrm{F}^{-}, \mathrm{SO}_{4}{ }^{2-}, \mathrm{BrO}_{3}{ }^{-}, \mathrm{NO}_{3}{ }^{-}, \mathrm{Br}^{-}$and $\mathrm{ClO}_{4}{ }^{-}$. These results suggest that the anion uptake on $\mathrm{CPC}$-montmorillonite proceeds through anion-exchange process, and the anion affinity of CPC-montmorillonite becomes $\mathrm{F}^{-}<\mathrm{SO}_{4}{ }^{2-}<\mathrm{BrO}_{3}{ }^{-}<\mathrm{NO}_{3}{ }^{-}<\mathrm{Br}^{-}<\mathrm{ClO}_{4}{ }^{-}$. The $\mathrm{ClO}_{4}{ }^{-}$ concentration in effluent solution passing through the CPC-montmorillonite bed falls below detection limits of ion chromatography up to 4,500 bed volumes (BV) at the feed solution rate of space velocity (SV) $15 \mathrm{~h}^{-1}$, thus the $\mathrm{ClO}_{4}^{-}$ion in the tap water can be reduced to less than $0.025 \mathrm{mg} \mathrm{dm}^{-3}$ of the target value under consideration as a standard of water-purity for tap water at Ministry of Health, Labour and Welfare of Japan. The $\mathrm{ClO}_{4}^{-}$concentration increases gradually between 5,000 and 10,000 of BV and becomes nearly constant at above near 10,000 of $\mathrm{BV}$. The $\mathrm{ClO}_{4}{ }^{-}$uptake amount on the column experiment can be estimated as $0.04 \mathrm{mmol} \mathrm{g}^{-1}$ from the adsorption breakthrough curve of $\mathrm{ClO}_{4}{ }^{-}$ion. During 37 consecutive days of column experiment, $86 \%$ of hexadecylpyridinium chloride molecules were eluted from an interlayer of CPC-montmorillonite and the basal spacing, (001) plane, of CPCmontmorillonite decreased from $4.05 \mathrm{~nm}$ to $2.11 \mathrm{~nm}$.
\end{abstract}

Keywords: Ion exchange, Perchlorate ion, Tap water, Anion selectivity, Montmorillonite, CPC

\section{Introduction}

Perchlorate salts are strong oxidant and are used in solid propellants for missiles and rockets, pyrotechnic materials and detonators for air-bags in vehicles. Their use leads to the release of perchlorate salts into the environment ${ }^{1}$. The presence of perchlorate ion in dairy milk and human milk had been reported in Japan and United States ${ }^{2-4}$. The perchlorate ion is similar in size of iodide ion and it can interfere with delivery of iodide ion to thyroid gland in the body. In this way, perchlorate can disrupt the production of thyroid hormones, and thus disrupt metabolism ${ }^{5}$. Regular ingestion of perchlorate ion might therefore be associated with a risk of disorder of child development. Ministry of Health, Labour and Welfare of Japan is considering carefully whether to establish an upper limit $\left(0.025 \mathrm{mg} \mathrm{dm}^{-3}\right)$ of perchlorate ion on a standard of waterpurity for tap water.

An adsorption process might be best suitable to remove the perchlorate in water, since some of the adsorbents show high selectivity toward $\mathrm{ClO}_{4}{ }^{-}$ion ${ }^{6-10)}$ compared with other process such as biological process ${ }^{11)}$ and electrochemical process ${ }^{12,13)}$. Recently, authors have reported that a CPC-montmorillonite exhibited excellent selectivity toward $\mathrm{ClO}_{4}{ }^{-}$ion ${ }^{14)}$. The $\mathrm{ClO}_{4}{ }^{-}$ uptake capacity of $1.02 \mathrm{mmol} \mathrm{g}^{-1}$ by CPC-montmorillonite is comparable to $1.1 \mathrm{mmol} \mathrm{g}^{-1}$ of most efficient perchlorate

\footnotetext{
* Corresponding author

E-mail: y-makita@aist.go.jp
} 
selective strong-base anion exchange resin ${ }^{6,7)}$. The anion uptake on CPC-montmorillonite accompanied with release of chloride ion into solution through anion-exchange processes and the CPC-montmorillonite displayed exceptional selectivity for $\mathrm{ClO}_{4}{ }^{-}$ion with the sequence $\mathrm{H}_{2} \mathrm{PO}_{4}{ }^{-}<\mathrm{SO}_{4}{ }^{2-}<\mathrm{NO}_{3}{ }^{-}<\mathrm{ClO}_{4}{ }^{-}$ similar to the Hofmeister series of anions based on the free energy of hydration ${ }^{15}$. In addition, authors have reported that the CPC-montmorillonite exhibited high selectivity toward $\mathrm{BrO}_{3}{ }^{-}$ion ${ }^{16)}$. The $\mathrm{BrO}_{3}^{-}$ion is human carcinogen ${ }^{17)}$ and is formed by ozonation of water ${ }^{18)}$. Consequently, regulatory agencies in the USA, European countries, and Japan established a maximum contaminant level of bromate of $0.01 \mathrm{mg} \mathrm{dm}{ }^{3}$ in drinking water. In the present study, removal of $\mathrm{ClO}_{4}{ }^{-}$ion or both $\mathrm{ClO}_{4}^{-}$and $\mathrm{BrO}_{3}^{-}$ions in tap water with the CPCmontmorillonite was investigated by column chromatography.

\section{Experimental}

\subsection{Materials}

CPC-montmorillonite was synthesized using natural Namontmorillonite and hexadecylpyridinium chloride $\left(\mathrm{C}_{12} \mathrm{H}_{38} \mathrm{NCl}\right.$, cetylpyridinium chloride, CPC) monohydrate. The Namontmorillonite (product name Kunipia-F) supplied by Kunimine Industries Co., Japan is a layered clay which has a cation exchange capacity of 1.19 meq $\mathrm{g}^{-1}$. The hexadecylpyridinium chloride monohydrate was of a special grade chemical supplied by Wako Pure Chemical Industries Ltd., Japan.

$\mathrm{A} \mathrm{ClO}_{4}{ }^{-}$ion or both $\mathrm{ClO}_{4}{ }^{-}$and $\mathrm{BrO}_{3}{ }^{-}$ions enriched tap water were used to evaluate the performance of perchlorate ion removal with the CPC-montmorillonite. A public drinking water that authors use daily was used as the tap water. The $\mathrm{NaClO}_{4} \cdot \mathrm{H}_{2} \mathrm{O}$ and $\mathrm{NaBrO}_{3}$ used for preparation of the $\mathrm{ClO}_{4}{ }^{-}$ion or both $\mathrm{ClO}_{4}{ }^{-}$and $\mathrm{BrO}_{3}{ }^{-}$ions enriched tap water were of special grade chemicals supplied by Wako Pure Chemical Industries Ltd., Japan.

\subsection{Synthesis of CPC- montmorillonite}

The CPC-montmorillonite was prepared at room temperature in the same way as the literature ${ }^{14)}$. Na-montmorillonite $(5 \mathrm{~g})$ was dispersed in deionized water $\left(500 \mathrm{~cm}^{3}\right)$ and stirred for 90 min. An amount of CPC (10.5 g) corresponding to four times the cation exchange capacity of the Na-montmorillonite was dissolved in deionized water $\left(250 \mathrm{~cm}^{3}\right)$ preheated to $60^{\circ} \mathrm{C}$. The CPC solution was added slowly to the dispersion and the dispersion was stirred at $500 \mathrm{rpm}$ for 1 day at room temperature. Solid products were separated by centrifugation, washed with deionized water, and dried at $40^{\circ} \mathrm{C}$ for $1 \mathrm{~d}$ ay. The sample was ground by a grinding mill (Model A10; Janke \& Kunkel IKA Labortechnik) and was sieved in size from 0.063 to $1 \mathrm{~mm}$ using two standard sieves, for column chromatography.

\subsection{Structural Analysis}

Structure analysis was carried out using an X-ray diffractometer (RINT 2100; Rigaku Co., Ltd.), operating at 40
$\mathrm{kV}$ voltage and $24 \mathrm{~mA}$ current, with $\mathrm{CuK} \alpha$ radiation $(\lambda=0.154052 \mathrm{~nm})$. The X-ray diffraction (XRD) pattern of sample was collected with sampling width of 0.0 ander scanning rate of $1^{\circ} \mathrm{min}^{-1}$.

Thermal analysis was carried out using a thermogravimetric analyzer (Thermo plus TG8110; Rigaku Co., Ltd.) in a flowing air atmosphere $\left(100 \mathrm{~cm}^{3} \mathrm{~min}^{-1}\right)$. The TG-DTA data of sample was collected with a heating rate of $10{ }^{\circ} \mathrm{C} \mathrm{min}^{-1}$.

\subsection{Column Chromatography for Removal of Perchlorate Ion in a Tap Water}

Removal of perchlorate ion in a tap water was investigated by column chromatography at two different feed solution rates. The column experiments were carried out at $25{ }^{\circ} \mathrm{C}$ in temperaturecontrolled room and the experiment was denoted by TEST 1 or TEST 2. For the TEST 1, a $0.82 \mathrm{~g}$ of CPC-montmorillonite was packed to $70.0 \mathrm{~mm}$ height in a chromatographic glass column (5 $\mathrm{mm}$ in diameter and $100 \mathrm{~mm}$ in length). The bed volume (BV) of CPC-montmorillonite was $1.37 \mathrm{~cm}^{3}$. A feed solution which contains $0.005 \mathrm{mmol} \mathrm{dm}^{-3}$ of $\mathrm{ClO}_{4}^{-}$in tap water was prepared by dissolving $10 \mathrm{~cm}^{3}$ of $1 \mathrm{mmol} \mathrm{dm} \mathrm{NaClO}_{4}$ in $1.99 \mathrm{dm}^{3}$ of tap water and was passed downward through the column at the flow rate of $7.3 \mathrm{~cm}^{3} \mathrm{~h}^{-1}\left(\mathrm{SV} 5 \mathrm{~h}^{-1}\right)$ with a plunger pump. For the TEST 2, the same amount of CPC-montmorillonite as TEST 1 was packed in the chromatographic glass column. A feed solution which contains $0.005 \mathrm{mmol} \mathrm{dm}^{-3}$ of $\mathrm{ClO}_{4}{ }^{-}$and $\mathrm{BrO}_{3}{ }^{-}$ ions in tap water was prepared by dissolving $100 \mathrm{~cm}^{3}$ of mixed solution of $1 \mathrm{mmol} \mathrm{dm}^{-3} \mathrm{NaClO}_{4}$ and $1 \mathrm{mmol} \mathrm{dm}^{-3} \mathrm{NaBrO}_{3}$ in $9.9 \mathrm{dm}^{3}$ of tap water and was passed downward through the column at the flow rate of $20.5 \mathrm{~cm}^{3} \mathrm{~h}^{-1}\left(\mathrm{SV} 15 \mathrm{~h}^{-1}\right)$. The column experiments of TEST 1 and TEST 2 took 90 and 37 days, respectively. For both TEST 1 and TEST 2, the feed solutions were reprepared when needed, up to breakthrough of perchlorate ion. In actually, the concentration of anion such as chloride, sulfate, nitrate and other minor ions in the feed solution changed at every preparation, because each anion concentration in a tap water varied from day to day. For exactly the same reason, the concentration of cation also changed at every preparations. The anion concentrations in tap water used for TEST 1 and TEST 2 were provided with dashed lines in Figs. 4 and 5, respectively. The concentrations of main cations in tap water were in the range 5.01 to $6.14 \mathrm{mg} \mathrm{dm}^{-3}$ for $\mathrm{Na}^{+}$ion, 0.990 to 1.39 for $\mathrm{K}^{+}, 1.38$ to 1.88 for $\mathrm{Mg}^{2+}$ and 8.47 to 10.6 for $\mathrm{Ca}^{2+}$. The solution $\mathrm{pH}$ of tap water was in the range 7.2 to 7.5. The effluent through the column was collected by every 1 hour using an automatic sample collector. The anion concentrations in selected fractions were measured by ion chromatography (761 Compact IC; Metrohm AG).

\section{Results and Discussion}

\subsection{Crystal Structure of CPC-Montmorillonite}

Figs. 1a and 1b show X-ray diffraction patterns of natural Na-montmorillonite and synthetic CPC-montmorillonite, 
respectively. The basal spacing, (001) plane, of the CPCmontmorillonite increased to $4.05 \mathrm{~nm}$ after modified with $\mathrm{CPC}$ from $1.26 \mathrm{~nm}$ of Na-montmorillonite. The basal spacing of 4.05 $\mathrm{nm}$ shows well agreement with that of $4.16 \mathrm{~nm}$ reported previously ${ }^{14)}$. The small difference of basal spacing might be due to the amount of CPC intercalated between layers of montmorillonite. Contents of $\mathrm{Na}^{+}, \mathrm{K}^{+}, \mathrm{Mg}^{2+}$ and $\mathrm{Ca}^{2+}$ between layers of montmorillonite are given in Table 1. The contents were calculated from the amounts of dissolved cations from interlayer on acid treatment. The value for $\mathrm{Mg}^{2+}$ includes the dissolved $\mathrm{Mg}^{2+}$ ions from intralayer. Montmorillonite sample of $250 \mathrm{mg}$ was dispersed in $100 \mathrm{mmol} \mathrm{dm}{ }^{-3} \mathrm{HCl}$ solution of $25 \mathrm{~cm}^{3}$ at room temperature and shaken frequently for $24 \mathrm{~h}$. For the Namontmorillonite, $\mathrm{Na}^{+}$ions are located mainly in the interlayer and $\mathrm{K}^{+}, \mathrm{Mg}^{2+}$ and $\mathrm{Ca}^{2+}$ ions are located rarely. The $1.1 \mathrm{mmol} \mathrm{g}^{-1}$ of $\mathrm{Na}^{+}$content is in good agreement with $1.19 \mathrm{meq} \mathrm{g}^{-1}$ of the

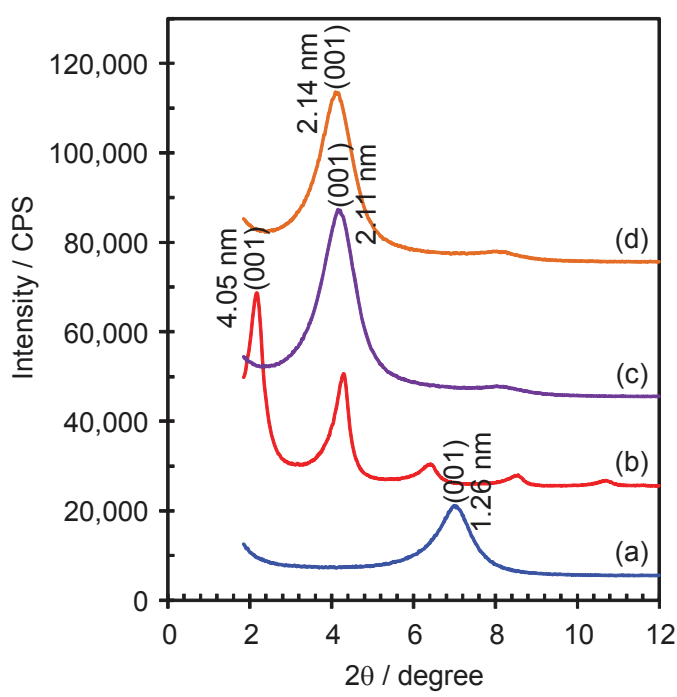

Fig. 1 XRD patterns of natural Na-montmorillonite (a), synthetic CPC-montmorillonite (b), CPCmontmorillonite after TEST 1 (c), and CPCmontmorillonite after TEST 2 (d).

Table 1 Cation contents in interlayer of montmorillonite.

\begin{tabular}{|c|c|c|c|c|}
\hline \multirow{2}{*}{ Sample } & \multicolumn{4}{|c|}{ Cation content $/ \mathrm{mmol} \mathrm{g}^{-1}$} \\
\hline & $\mathrm{Na}^{+}$ & $\mathrm{K}^{+}$ & $\mathrm{Mg}^{2+*}$ & $\mathrm{Ca}^{2+}$ \\
\hline Na-mont. & $1.1 \times 10^{0}$ & $1.4 \times 10^{-2}$ & $2.5 \times 10^{-2}$ & $3.8 \times 10^{-2}$ \\
\hline CPC-mont. & $1.4 \times 10^{-3}$ & $7.9 \times 10^{-4}$ & $3.0 \times 10^{-3}$ & $2.2 \times 10^{-5}$ \\
\hline $\begin{array}{l}\text { CPC-mont. } \\
\text { after TEST } 1\end{array}$ & $1.5 \times 10^{-3}$ & $1.1 \times 10^{-3}$ & $1.7 \times 10^{-3}$ & $8.0 \times 10^{-5}$ \\
\hline $\begin{array}{l}\text { CPC-mont. } \\
\text { after TEST } 2\end{array}$ & $1.1 \times 10^{-3}$ & $7.1 \times 10^{-4}$ & $1.7 \times 10^{-3}$ & $1.0 \times 10^{-4}$ \\
\hline
\end{tabular}

* The value includes $\mathrm{Mg}^{2+}$ ion dissolved from intralayer. cation exchange capacity of Na-montmorillonite. Conversely, $\mathrm{Na}^{+}, \mathrm{K}^{+}, \mathrm{Mg}^{2+}$ and $\mathrm{Ca}^{2+}$ ions hardly exist in interlayer of CPCmontmorillonite. These results indicate that almost $\mathrm{Na}^{+}$ions of Na-montmorillonite exchanged with the hexadecylpyridinium ions $\left(\mathrm{CP}^{+}\right)$.

Figs. 2a, 2b and 2c show thermogravimetric curves of natural Na-montmorillonite, synthetic CPC-montmorillonite and CPC monohydrate, respectively. The weight loss of Namontmorillonite became $8.3 \%$ at the temperature below $110{ }^{\circ} \mathrm{C}$, nearly zero in the range 110 to $600 \mathrm{C}$ and $3.9 \%$ in the range 600 to $800 \mathrm{C}$. The former weight loss corresponds to the amounts of the surface water and hydrated water of interlayer cation and the later weight loss might be due to a partial collapse of crystal structure. The weight loss of CPCmontmorillonite became $3.7 \%$ at the temperature below $110^{\circ} \mathrm{C}$ and $56.6 \%$ in the range 110 to $800^{\circ} \mathrm{C}$. The weight loss of CPC monohydrate became $98 \%$ at the temperature below 280 .

These results indicate that the hydrated water of $\mathrm{CP}^{+}$in $\mathrm{CPC}$ montmorillonite is less than half that of $\mathrm{Na}^{+}$in Namontmorillonite and the weight loss of CPC-montmorillonite in the range 110 to $800^{\circ} \mathrm{C}$ is due to a thermal decomposition of $\mathrm{CP}^{+}$and $\mathrm{CPC}$ molecule between layers of montmorillonite mainly and a partial collapse of the layers.

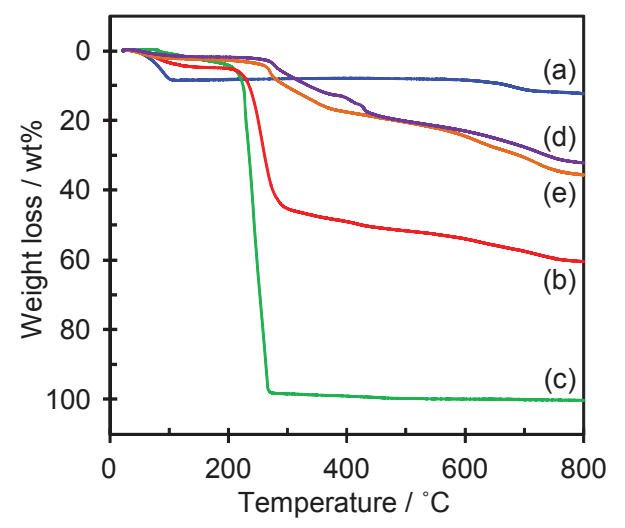

Fig. 2 Thermogravimetric curves of natural $\mathrm{Na}-$ montmorillonite (a), synthetic CPC-montmorillonite (b), CPC monohydrate (c), CPC-montmorillonite after TEST 1 (d), and CPC-montmorillonite after TEST 2 (e).

The contents of aluminosilicate layers of CPCmontmorillonite and of $\mathrm{CP}^{+}$ions and $\mathrm{CPC}$ molecules between the layers were calculated from the weight losses in the range 110 to $800^{\circ} \mathrm{C}$ from the thermogravimetric analysis, as given in Table 2, on the assumption that $\mathrm{Na}^{+}$ions of $1.19 \mathrm{mmol} \mathrm{g}^{-1}$ corresponding to the cation exchange capacity of $\mathrm{Na}-$ montmorillonite were ion-exchanged to $\mathrm{CP}^{+}$from the result given in Table 1. The contents of layer, $\mathrm{CP}^{+}$ion and $\mathrm{CPC}$ molecule of CPC-montmorillonite were 41,16 and $43 \mathrm{wt} \%$, 
respectively. The $\mathrm{CPC}$ molecule content corresponds to 1.3 mmol g ${ }^{-1}$ of CPC and the value gives a theoretical limit of anion exchange capacity of CPC-montmorillonite, since the chloride ions of CPC molecules in CPC-montmorillonite can be ionexchanged for the anions except chloride ion in an aqueous medium. The $1.3 \mathrm{mmol} \mathrm{g}^{-1}$ of anion exchange capacity compares well with $1.02 \mathrm{mmol} \mathrm{g}^{-1}$ of $\mathrm{ClO}_{4}^{-}$uptake capacity calculated from a Langmuir fitting of a $\mathrm{ClO}_{4}{ }^{-}$uptake isotherm of CPCmontmorillonite determined at the initial $\mathrm{ClO}_{4}{ }^{-}$ion concentration of $0.50 \mathrm{mmol} \mathrm{dm}^{-3}$ (equilibrium $\mathrm{pH} \mathrm{5.8)}$ (4). $^{14}$.

Table 2 Contents of aluminosilicate layer, $\mathrm{CP}^{+}$ion and CPC molecule in montmorillonite.

\begin{tabular}{ccccc}
\hline \multirow{2}{*}{ Sample } & \multicolumn{4}{c}{ Content / wt\% $\left(\mathrm{mmol} \mathrm{g}^{-1}\right)$} \\
\cline { 2 - 5 } & layer & $\mathrm{CP}^{+}$ & $\mathrm{CPC}$ & $\mathrm{CP}^{+} \mathrm{ClO}_{4}$ \\
\hline \multirow{2}{*}{ Na-mont. } & \multirow{2}{*}{100} & 0 & 0 & - \\
& & 16 & 43 & - \\
CPC-mont. & 41 & $(0.5)$ & $(1.3)$ & \\
CPC-mont. & & 26 & 4 & 2 \\
after TEST 1 & 68 & $(0.8)$ & $(0.1)$ & $(0.05)$ \\
CPC-mont. & \multirow{2}{*}{65} & 25 & 8 & 2 \\
after TEST 2 & & $(0.8)$ & $(0.2)$ & $(0.04)$ \\
\hline
\end{tabular}

Considering the layer thickness of montmorillonite as 0.97 $\mathrm{nm}$ and the length of the CPC molecule as $2.31 \mathrm{~nm}^{19)}$, the CPCmontmorillonite with basal spacing of $4.05 \mathrm{~nm}$ suggests a bilayered arrangement of $\mathrm{CPC}$ in the interlayer space at the inclination angle of $42^{\circ}{ }^{14,16)}$, as shown in Fig. 3. The $\mathrm{Cl}^{-}$ions of CPC molecules exchange with anions in solution.

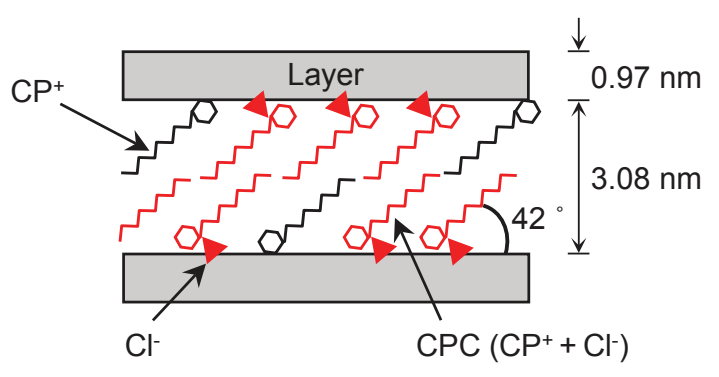

Fig. 3 Schematic crystal structure of CPC-montmorillonite.

\subsection{Removal of Perchlorate Ion in a Tap Water by Column Chromatography}

Fig. 4 shows adsorption breakthrough curves of anions on the column experiment TEST 1 fed the tap water containing $0.483 \mathrm{mg} \mathrm{dm}^{-3}$ on average of $\mathrm{ClO}_{4}{ }^{-}$ion at $\mathrm{SV} 5 \mathrm{~h}^{-1}$. The dashed lines in the figure indicate the ion concentrations in feed solution. The $\mathrm{ClO}_{4}{ }^{-}$ion in the feed solution can be effectively removed by passing through the $\mathrm{CPC}$-montmorillonite column, although the concentration of $\mathrm{ClO}_{4}{ }^{-}$ion is markedly lower than those of $\mathrm{Cl}^{-}, \mathrm{SO}_{4}{ }^{2-}$ and $\mathrm{NO}_{3}{ }^{-}$ions. The $\mathrm{ClO}_{4}{ }^{-}$ion concentration in effluent is not detected up to $4,700 \mathrm{BV}$ and breakthrough at around 5,000 BV. This indicates that the CPC-montmorillonite can reduce $\mathrm{ClO}_{4}{ }^{-}$ion concentration in tap water to less than $0.025 \mathrm{mg} \mathrm{dm}^{-3}$ of the target value under consideration as a standard of water-purity for tap water at Ministry of Health, Labour and Welfare of Japan. The $\mathrm{ClO}_{4}{ }^{-}$ion concentration increases gradually in the range of 5,000 $<\mathrm{BV}<7,000$ and becomes substantially constant at $\mathrm{BV}>7,000$.

The $\mathrm{Cl}^{-}$ion concentration decreases steeply in range 3 to around 1,000 BV and continues to decrease slowly up to the end of the column experiment. The $\mathrm{F}^{-}$concentration in effluent shows about the same concentration as the feed solution during
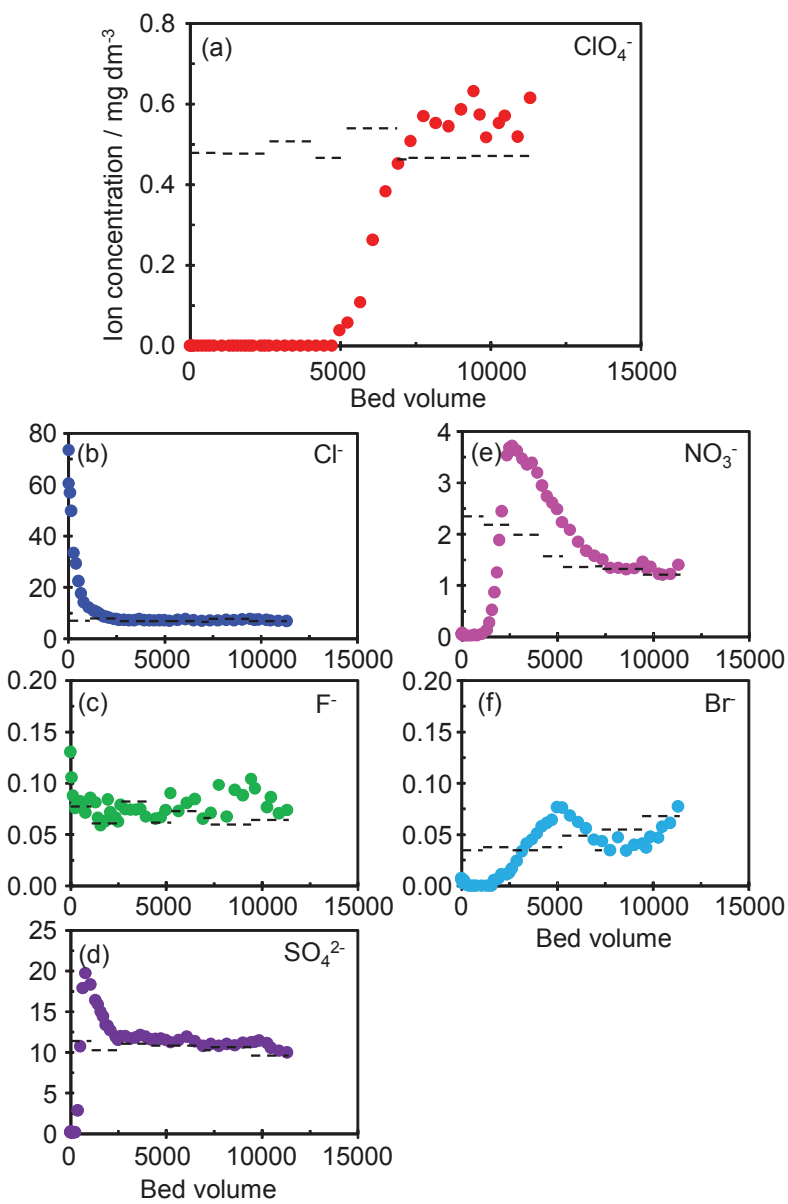

Fig. 4 Adsorption breakthrough curves of $\mathrm{ClO}_{4}{ }^{-}$(a), $\mathrm{Cl}^{-}$(b), $\mathrm{F}^{-}$(c), $\mathrm{SO}_{4}{ }^{2-}$ (d), $\mathrm{NO}_{3}^{-}$(e) and $\mathrm{Br}^{-}$(f) on the column experiment TEST 1 fed the tap water containing $\mathrm{CIO}_{4}{ }^{-}$ ion at SV $5 \mathrm{~h}^{-1}$. Vertical and horizontal axes represent ion concentration $\left(\mathrm{mg} \mathrm{dm}^{-3}\right)$ and bed volume, respectively. Dashed lines indicate the ion concentration in feed solution. 
the column experiment. This result suggests that the CPCmontmorillonite adsorbs very little $\mathrm{F}^{-}$ion. The concentrations of $\mathrm{SO}_{4}{ }^{2-}, \mathrm{NO}_{3}{ }^{-}$and $\mathrm{Br}^{-}$ions in effluent decrease to almost zero at the beginning of the column experiment and the anion exhibits breakthrough in the order of $\mathrm{SO}_{4}{ }^{2-}, \mathrm{NO}_{3}{ }^{-}, \mathrm{Br}^{-}$and $\mathrm{ClO}_{4}{ }^{-}$.

Fig. 5 shows adsorption breakthrough curves of anions on the column experiment TEST 2 fed the tap water containing 0.518 and $0.540 \mathrm{mg} \mathrm{dm}^{-3}$ on averages of $\mathrm{ClO}_{4}{ }^{-}$and $\mathrm{BrO}_{3}{ }^{-}$ions at $\mathrm{SV} 15 \mathrm{~h}^{-1}$. The $\mathrm{ClO}_{4}^{-}$ion concentration in effluent is not detected up to 4,500 BV and breakthrough at around 5,000 BV as is the case of TEST 1 . This result indicates that the $\mathrm{ClO}_{4}{ }^{-}$ion in the tap water can be effectively removed by column chromatography with $\mathrm{CPC}$-montmorillonite under at least the $\mathrm{SV} 15 \mathrm{~h}^{-1}$ of the feed solution rate, since the $\mathrm{ClO}_{4}^{-}$ion is adsorbed relatively quickly to $\mathrm{CPC}$-montmorillonite. Authors
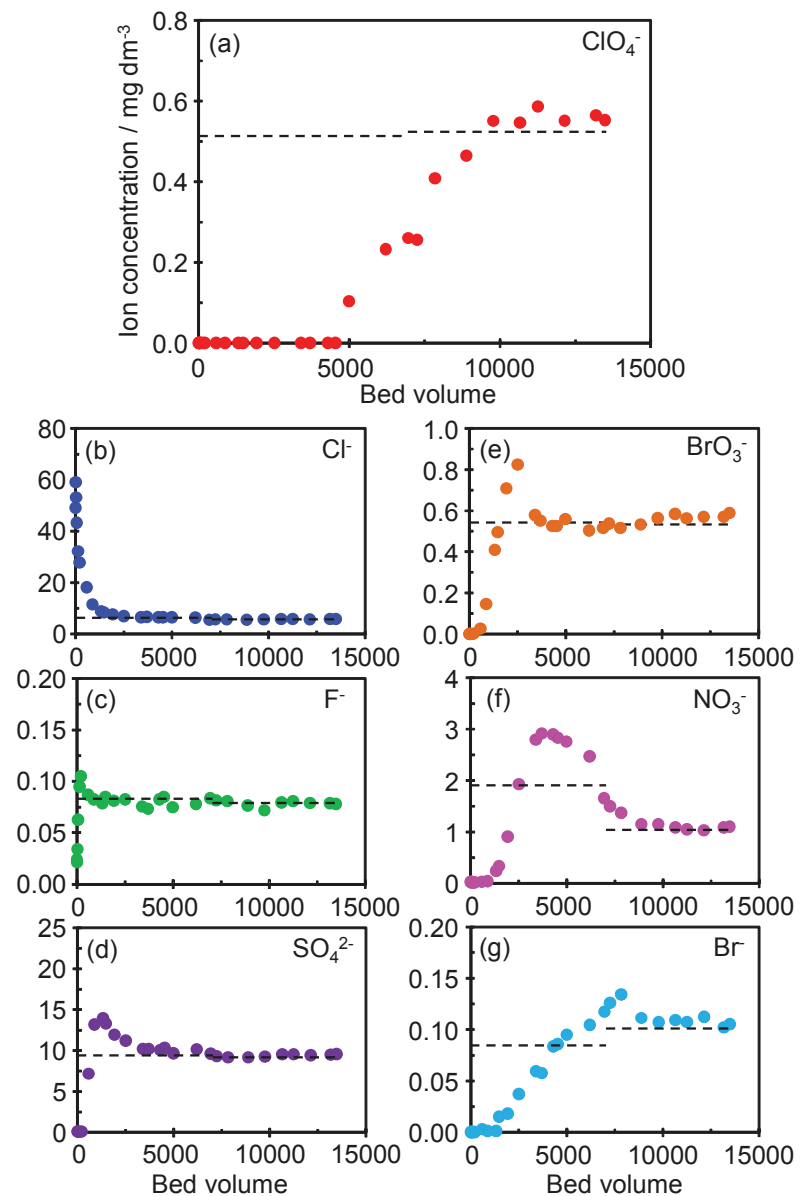

Fig. 5 Adsorption breakthrough curves of $\mathrm{ClO}_{4}^{-}$(a), $\mathrm{Cl}^{-}(\mathrm{b})$, $\mathrm{F}^{-}$(c), $\mathrm{SO}_{4}{ }^{2-}$ (d), $\mathrm{BO}_{3}{ }^{-}$(e), $\mathrm{NO}_{3}{ }^{-}$(f) and $\mathrm{Br}^{-}$(g) on the column experiment TEST 2 fed the tap water containing $\mathrm{ClO}_{4}{ }^{-}$and $\mathrm{BrO}_{3}{ }^{-}$ions at SV $15 \mathrm{~h}^{-1}$. Vertical and horizontal axes represent ion concentration $(\mathrm{mg}$ $\mathrm{dm}^{-3}$ ) and bed volume, respectively. Dashed lines indicate the ion concentrations in feed solution. have reported that the $\mathrm{ClO}_{4}{ }^{-}$ion uptake of $\mathrm{CPC}$-montmorillonite reached equilibrium within $4 \mathrm{~h}$ with an uptake amount of 0.75 $\mathrm{mmol} \mathrm{g}^{-1}$ at $\mathrm{pH} 5.8$ from the initial concentration of $0.10 \mathrm{mmol}$ $\mathrm{dm}^{-3} \mathrm{NaClO}_{4}$ solution by a study of the kinetics on perchlorate uptake $^{14)}$, much higher than that reported for SBA-15 $(0.55$ mmol g${ }^{-120)}$, MCM-41 $\left(0.27 \mathrm{mmol} \mathrm{g}^{-1}\right)^{21)}$, Na-1-mica modified with hexadecyltrimethylammonium $\left(0.35 \mathrm{mmol} \mathrm{g}^{-1}\right)^{22)}, \mathrm{MgAl}-$ $\mathrm{LDH}\left(\mathrm{NO}_{3}\right)\left(0.20 \mathrm{mmol} \mathrm{g}^{-1}\right)^{22)}$, granular activated carbon coated with hexadecyltrimethylammonium bromide ${ }^{23)}$, or granular ferric hydroxide $\left(0.03 \mathrm{mmol} \mathrm{g}^{-1}\right)^{24)}$. The $\mathrm{ClO}_{4}{ }^{-}$ion concentration after the breakthrough increases slowly compared to that on TEST 1 in the range of $5,000<\mathrm{BV}<10,000$ and became close to that in the feed solution at $\mathrm{BV}>10,000$.

The adsorption breakthrough curves of other anions on TEST 2 show the same tendency of those on TEST 1. The concentrations of $\mathrm{SO}_{4}{ }^{2-}, \mathrm{BrO}_{3}{ }^{-}, \mathrm{NO}_{3}{ }^{-}$and $\mathrm{Br}^{-}$ions in effluent decrease to almost zero at the beginning of the column experiment and the anion exhibits breakthrough in the order of $\mathrm{SO}_{4}{ }^{2-}, \mathrm{BrO}_{3}^{-}, \mathrm{NO}_{3}^{-}, \mathrm{Br}^{-}$and $\mathrm{ClO}_{4}^{-}$. These results indicate that CPC-montmorillonite adsorbs $\mathrm{ClO}_{4}{ }^{-}$ion preferably than $\mathrm{BrO}_{3}{ }^{-}$ ion and the anion affinity of CPC-montmorillonite becomes $\mathrm{F}^{-}<$ $\mathrm{SO}_{4}{ }^{2-}<\mathrm{BrO}_{3}{ }^{-}<\mathrm{NO}_{3}^{-}<\mathrm{Br}^{-}<\mathrm{ClO}_{4}^{-}$. In our previous studies $^{14,16)}$, we have reported that the selectivity of $\mathrm{CPC}$ montmorillonite became $\mathrm{H}_{2} \mathrm{PO}_{4}{ }^{-}<\mathrm{SO}_{4}{ }^{2-}<\mathrm{NO}_{3}{ }^{-}<\mathrm{ClO}_{4}{ }^{-}$and $\mathrm{H}_{2} \mathrm{PO}_{4}{ }^{-}<\mathrm{SO}_{4}{ }^{2-}<\mathrm{BrO}_{3}{ }^{-}<\mathrm{Br}^{-}<\mathrm{NO}_{3}{ }^{-}$based on the distribution coefficients of anions on the batch adsorption experiments with multi-anion solution of $0.1,1.0$ or $2.0 \mathrm{mmol} \mathrm{dm}^{-3}$. The affinity order of $\mathrm{Br}^{-}$and $\mathrm{NO}_{3}{ }^{-}$ions on the present column study is different with the selectivity order on the previous batch study. Since the concentrations of $\mathrm{Br}^{-}$and $\mathrm{NO}_{3}{ }^{-}$ions in the tap water used in the present study are around 0.02 and $0.01 \mathrm{mmol} \mathrm{dm}^{-3}$, respectively, CPC-montmorillonite probably adsorbs $\mathrm{Br}^{-}$ion preferably than $\mathrm{NO}_{3}{ }^{-}$ion at the low concentration.

It is noticeable that the concentrations of $\mathrm{SO}_{4}{ }^{2-}, \mathrm{BrO}_{3}{ }^{-}, \mathrm{NO}_{3}{ }^{-}$ and $\mathrm{Br}^{-}$ions exceed those of the feed solution markedly after the breakthrough, though they become finally about the same concentration as the feed solution. The reason why is that the exchanged anion into CPC-montmorillonite are excluded from the site by the exchange with other anion having a higher affinity. Conversely, the $\mathrm{ClO}_{4}{ }^{-}$ion concentration increases up to the same level as that of the feed solution without a large exceedance. The exchanged $\mathrm{ClO}_{4}{ }^{-}$ion might not be excluded by any anion, since the CPC-montmorillonite shows the highest affinity toward $\mathrm{ClO}_{4}{ }^{-}$ion among the anions.

Table 3 shows the amounts of released chloride ion and adsorbed anions estimated from the adsorption breakthrough curves in Figs. 4 and 5. The $\mathrm{ClO}_{4}{ }^{-}$uptake amounts on TEST 1 and TEST 2 gave 0.05 and $0.04 \mathrm{mmol} \mathrm{g}^{-1}$, respectively. The amounts of adsorbed $\mathrm{F}^{-}, \mathrm{SO}_{4}{ }^{2-}, \mathrm{BrO}_{3}{ }^{-}, \mathrm{NO}_{3}{ }^{-}$and $\mathrm{Br}^{-}$ions gave less than or equal to zero $\mathrm{mmol} \mathrm{g}^{-1}$. Though some anions gave negative values, the values are believed to be almost zero mmol $\mathrm{g}^{-1}$, because there is no way that the uptake amount gives a 
negative value theoretically. These results support that the exchanged anion in CPC-montmorillonite are excluded from the site by the exchange with other anion having a higher affinity and only $\mathrm{ClO}_{4}{ }^{-}$ions having the highest affinity might be finally remained in CPC-montmorillonite. The amount of released $\mathrm{Cl}^{-}$ ion is markedly higher than that of adsorbed $\mathrm{ClO}_{4}{ }^{-}$ion. This result suggests that the release of $\mathrm{Cl}^{-}$ion is caused by the elution of CPC molecule mainly and the partial anion exchange.

Table 3 Amounts of released chloride ion and adsorbed anions estimated from the adsorption breakthrough curves in Figs. 4 and 5 .

\begin{tabular}{ccccccccc}
\hline & \multicolumn{6}{c}{ Amounts of released $\mathrm{Cl}^{-}$and adsorbed anions $/ \mathrm{mmol} \mathrm{g}^{-1}$} \\
\cline { 2 - 8 } & $\mathrm{Cl}^{-}$ & $\mathrm{ClO}_{4}{ }^{-}$ & $\mathrm{F}^{-}$ & $\mathrm{SO}_{4}{ }^{2-}$ & $\mathrm{BrO}_{3}{ }^{-}$ & $\mathrm{NO}_{3}{ }^{-}$ & $\mathrm{Br}^{-}$ \\
\hline 1 & 1.15 & 0.05 & $<0$ & $<0$ & - & $<0$ & 0.00 \\
2 & 0.48 & 0.04 & 0.00 & $<0$ & 0.00 & $<0$ & 0.00 \\
\hline
\end{tabular}

\subsection{CPC-Montmorillonite after the Column Experiment}

Figs. 1c and 1d show XRD patterns of CPC-montmorillonite after column experiments of TEST 1 and TEST 2, respectively. The basal spacing, (001) plane, decreased to $2.11 \mathrm{~nm}$ for TEST 1 and $2.14 \mathrm{~nm}$ for TEST 2 from $4.05 \mathrm{~nm}$ of CPCmontmorillonite in Fig. 1b. Figs. $2 \mathrm{~d}$ and $2 \mathrm{e}$ show thermogravimetric curves of CPC-montmorillonite after TEST 1 and TEST 2, respectively. The weight losses of CPCmontmorillonite after TEST 1 and TEST 2 at the temperature below $110^{\circ} \mathrm{C}$ were 1.3 and $2.1 \mathrm{wt} \%$, respectively. This result indicates that the hydrated water of $\mathrm{CP}^{+}$in $\mathrm{CPC}$ montmorillonite is much lower than that of $\mathrm{Na}^{+}$in Namontmorillonite. The weight losses of CPC-montmorillonite after TEST 1 and TEST 2 in the range 110 to $800^{\circ} \mathrm{C}$ were 30.8 and $33.3 \mathrm{wt} \%$, respectively. Table 1 shows that $\mathrm{CP}^{+}$ions remain in interlayer of CPC-montmorillonite after TEST 1 and TEST 2, since $\mathrm{Na}^{+}, \mathrm{K}^{+}, \mathrm{Mg}^{2+}$ and $\mathrm{Ca}^{2+}$ ions hardly exist in the interlayer. These results suggest that the amount of CPC molecules in CPC-montmorillonite decrease during the long-term column experiments.

The contents of aluminosilicate layers, $\mathrm{CP}^{+}$ions, $\mathrm{CPC}$ molecules and $\mathrm{CP}-\mathrm{ClO}_{4}$ molecules which exchanged $\mathrm{Cl}^{-}$ions in CPC for $\mathrm{ClO}_{4}{ }^{-}$ions of CPC-montmorillonite after TEST 1 and TEST 2 were calculated from the weight losses in the range 110 to $800^{\circ} \mathrm{C}$ from the thermogravimetric analysis and the $\mathrm{ClO}_{4}{ }^{-}$ uptake amounts of $0.05 \mathrm{mmol} \mathrm{g}^{-1}$ for TEST 1 and $0.04 \mathrm{mmol} \mathrm{g}^{-1}$ for TEST 2, as given in Table 2. Since the $\mathrm{CP}^{+}$ions between layers of CPC-montmorillonite is not exchanged for any cations in the tap water, the ratios of $\mathrm{CP}^{+}$to layer after TEST 1 and TEST 2 coincide with that of CPC-montmorillonite before column experiment. When the weight of layer of samples is normalized as $1, \mathrm{CPC}$ and $\mathrm{CP}-\mathrm{ClO}_{4}$ values become 1.05 and 0.0 for CPC-montmorillonite, 0.057 and 0.030 for CPCmontmorillonite after TEST 1 and 0.12 and 0.023 for CPCmontmorillonite after TEST 2, respectively. These results suggest that the CPC of CPC-montmorillonite is eluted during the long-term column experiment. The decreases become 92 mol\% for TEST 1 on 90 consecutive days and $86 \mathrm{~mol} \%$ for TEST 2 on 37 consecutive days.

The CPC molecule is used for sterilization of throat in a mouthwash, since it exerts bactericidal effect. Therefore, the desorption of CPC from CPC-montmorillonite might not causes a health damage, even if a small amount of CPC molecule is contaminated in the drinking water.

\section{Conclusions}

The $\mathrm{ClO}_{4}{ }^{-}$ion in the tap water can be effectively removed by passing through the CPC-montmorillonite column and be reduced to less than $0.025 \mathrm{mg} \mathrm{dm}^{-3}$ of the target value under consideration as a standard of water-purity for tap water at Ministry of Health, Labour and Welfare of Japan. The anion affinity of CPC-montmorillonite on the present study becomes in the order of $\mathrm{F}^{-}<\mathrm{SO}_{4}{ }^{2-}<\mathrm{BrO}_{3}{ }^{-}<\mathrm{NO}_{3}{ }^{-}<\mathrm{Br}^{-}<\mathrm{ClO}_{4}{ }^{-}$from the adsorption breakthrough curves of anions on the column experiment. The $\mathrm{ClO}_{4}{ }^{-}$uptake amounts until the $\mathrm{ClO}_{4}{ }^{-}$ion concentration reaches to equilibrium after the breakthrough is estimated as about $0.05 \mathrm{mmol} \mathrm{g}^{-1}$. During the long-term experiment, about $90 \%$ of CPC molecules were eluted from an interlayer of CPC-montmorillonite and the basal spacing, (001) plane, of CPC-montmorillonite decreased from $4.1 \mathrm{~nm}$ to 2.1 $\mathrm{nm}$.

This work was supported by JSPS KAKENHI Grant Number 22550186 .

\section{References}

1) N. Bardiya and J. H. Bae, Microbiol.Res., 166, 237 (2011).

2) A. B. Kirk, E. E. Smith, K. Tian, T. A. Anderson and P. K. Dasgupta, Environ. Sci. Technol., 37, 4979 (2003).

3) A. B. Kirk, P. K. Martinelango, K. Tian, A. Dutta, E. E. Smith and P. K. Dasgupta, Environ. Sci. Technol., 39, 2011 (2005).

4) J. V. Dyke, K. Ito, T. Obitsu, Y. Hisamatsu, P. K. Dasgupta and B. C. Blount, Environ. Sci. Technol., 41, 88 (2007).

5) E. T. Urbansky, Environ. Sci. Pollut. Res., 9, 187 (2002).

6) B. Gu, Y. Ku and G. M. Brown, Environ. Sci. Technol., 39, 901 (2005).

7) B. Gu, G.M. Brown and C. Chiang, Environ. Sci. Technol., 41, 6277 (2007).

8) R. Parette and F. S. Cannon, Water Res., 39, 4020 (2005).

9) R. Parette, F. S. Cannon and K. Weeks, Water Res., 39, 
4683 (2005).

10) T. Hirakawa, M. Yamaguchi, N. Ito, M. Kondo, M. Miyazawa, N. Nishina, S. Yasue, K. Maeda and F. Uchida, Chem. Lett., 38, 290 (2009).

11) B. E. Logan, J. Wu and R. F. Unz, Water Res., 35, 3034 (2001).

12) C. Lee, B. Batchelor, S. H. Park, D. S. Han, A. AbdelWahab and T. A. Kramer, J. Hazard. Mater., 197, 183 (2011).

13) S. Zhang, Y. Shao, J. Liu, I. A. Aksay and Y. Lin, ACS Appl. Mater. Interfaces, 3, 3633 (2011).

14) R. Chitrakar, Y. Makita, T. Hirotsu and A. Sonoda, Chem. Eng. J., 191, 141 (2012).

15) R. Custelcean and B. A. Moyer, Eur. J. Inorg. Chem., 2007, 1321.

16) R. Chitrakar, Y. Makita, A. Sonoda and T. Hirotsu, Appl. Clay Sci., 51, 375 (2011).

17) D. Delker, G. Hatch, J. Allen, B. Crissman, M. George, D.
Geter, S. Kilburn, T. Moore, G. Nelson, B. Roop, R. Slade, A. Swank, W. Ward and A. DeAngelo, Toxicology, 221, 158 (2006).

18) U. von Gunten, Water Res., 37, 1469 (2003).

19) J. Bors, A. Patzko and I. Dekany, Appl. Clay Sci., 19, 27 (2001).

20) T. H. Kim, M. Jang and J.K. Park, Microporous Mesoporous Mater., 108, 22 (2008).

21) S. Komarneni, J. Y. Kim, R. Parette and F. S. Cannon, $J$. Porous Mater., 17, 651 (2010).

22) J. Y. Kim, S. Komarneni, R. Parette, F. S. Cannon and H. Katsuki, Appl. Clay Sci., 51, 158 (2011).

23) J. H Xu, N. Y. Gao, Y. Deng, M. H. Sui and Y. L. Tang, J. Colloid Interface Sci., 357, 474 (2011).

24) E. Kumar, A. Bhatnagar, J. A. Choi, U. Kumar, B. Min, Y. Kim, H. Song, K. J. Paeng, Y. M. Jung, R. A. I. AbouShanab and B. H. Jeon, Chem. Eng. J., 159, 84 (2010). 